Southern Illinois University Edwardsville

SPARK

SIUE Faculty Research, Scholarship, and Creative Activity

Spring 2-9-2016

\title{
The Isolated Islamists: The Case of the Allied Democratic Forces in the Ugandan-Congolese Borderland
}

Suranjan Weeraratne

Southern Illinois University Edwardsville, sweerar@siue.edu

Sterling Recker

Southern Illinois University Edwardsville, srecker@siue.edu

Follow this and additional works at: http://spark.siue.edu/siue_fac

Part of the Comparative Politics Commons, and the International Relations Commons

\section{Recommended Citation}

Suranjan Weeraratne \& Sterling Recker (2016): The isolated Islamists: The case of the Allied Democratic Forces in the UgandanCongolese borderland, Terrorism and Political Violence, DOI: 10.1080/09546553.2016.1139577

This Article is brought to you for free and open access by SPARK. It has been accepted for inclusion in SIUE Faculty Research, Scholarship, and Creative Activity by an authorized administrator of SPARK. For more information, please contact gpark@siue.edu. 


\section{Cover Page Footnote}

This is an Accepted Manuscript of an article published by Taylor \& Francis in Terrorism and Political Violence on February 9, 2016, available online: http://dx.doi.org/10.1080/09546553.2016.1139577. 
This research explores why locally based Islamist militant groups, on occasion, tend to be unaffiliated or at best, loosely connected with broader transnational militant Islamist organizations such as Al-Qaeda or the Islamic State in Iraq and Syria (ISIS). This is an intriguing empirical puzzle given the extent of linkages that a vast multitude of localized Jihadists have forged with global/regional Jihadi counterparts such as Al-Qaeda. Using the Allied Democratic Forces (ADF) - a militant Islamist group operating in the Ugandan-Congolese borderland, as a detailed case study, this research investigates the conditions under which significant linkages with transnational Islamists are less likely.

The formation, durability and characteristics of alliances between terrorist groups have been the subjects of considerable academic scrutiny. ${ }^{1}$ In particular, many studies have explored the nature of alliance patterns between militant Islamist organizations with much research focused on the interaction between Al-Qaeda and its various affiliates. ${ }^{2}$

In a similar vein, this study limits itself to an examination of the relations (or lack thereof) between militant groups based on an Islamic ideology. This is primarily motivated by the preeminence of Al-Qaeda and its impressive array of ties with regional Islamists. Moreover, ISIS has rapidly emerged as a significant challenger to Al-Qaeda with a growing number of local and regional militant outfits pledging allegiance to the group. Given this context of ever expanding transnational ties, it is opportune to investigate why some militant Islamists do not develop links with one another. The study is further limited to groups espousing a broad Salafi Jihadist ideology. Such groups subscribe to a pious form of Islam, generally consonant with its early ancestors. Salafi Jihadists aim to return Islam to its pristine glory, overthrow apostate regimes, condemn non-conformists and eradicate detrimental outside influences. ${ }^{3}$ The focus on such movements is warranted given the 58\% increase in the number of Salafi-Jihadist groups 
from 2010-13. ${ }^{4}$ Restricting the study exclusively to Salafist groups also allows for greater conceptual clarity and facilitates making relevant generalizations.

The authors contend that in order to explain the absence of ties between some militant Islamist organizations, it is helpful to delineate the circumstances conducive to the development of such ties, in the first place. Studies show that alliances are more likely when a partnership confers mutual benefits to both parties. For instance, transnationals like Al-Qaeda gain by getting a wider platform to export their ideology and being offered safe havens in areas controlled by local militants. Locals, on the other hand, benefit through improved training, military experience, financial/logistical assistance and greater name recognition. As discussed later, there is much heterogeneity in the scope and strength of relations between local Islamists and their more transnational partners. Theorizing such variation (which ranges from official affiliation to vaguely suspected ties) is also useful for understanding why alliance patterns may be tenuous or non-existent in some cases. The strength of inter-Islamist linkages is contingent on myriad different factors. These include the extent of ideological incompatibility, the degree of salience to the local community and other relevant actors and apprehension at being a more visible target of counter-terrorist operations.

Based on the foregoing theoretical summary and an in-depth examination of the Allied Democratic Forces (ADF), this study advances the argument that meaningful linkages between the ADF and transnational Islamist movements such as Al-Qaeda or ISIS are unlikely, at least in the foreseeable future. First, while the ADF retains a nominally Salafi outlook, the importance accorded to an Islamist agenda in practice is ambiguous, at best. The ADF has been labeled as multi-layered and comprising of several disparate factions with varied grievances and agendas and there is no clear evidence that an extremist Jihadist agenda overrides ADF's worldview. ${ }^{5}$ 
Further, the ADF is presently active in an area that has less than $10 \%$ Muslim population and has very little history of radicalism. Hence, the ADF is unlikely to advance the ideological prerogatives of global Jihadists. Second, in spite of its Ugandan origins, the ADF has long been embedded in eastern Congolese society through extensive involvement in the economy and the informal trans-border trade, intermarriage and similar cultural traits. This has facilitated ADF's immersion into the larger Congolese conflict, provided collaborative opportunities with other rebel groups in the area and boosted the recruitment of Congolese non-Muslims into their ranks. The coexistence between the ADF and the local community, while being uneasy at times and punctuated with occasional civilian abuses by the ADF, has generally prevailed due to mutual interests. However, this relationship has sharply deteriorated since early 2013 as the ADF carried out numerous attacks against the civilian population in its area of operations. Given this context of rapidly worsening ties, an entrenched relationship with transnational Islamists could further aggravate tensions and is unlikely to resonate favorably with the local community. Third, the Ugandan government has often portrayed the ADF as an agent of Al-Qaeda in order to justify crackdowns and muster international support. Hence, more visible ties with external Islamist militants will likely invite ADF more attention from the Ugandan authorities as well as other regional/global actors. Therefore, the fear of attracting new enemies may serve as an effective deterrent against the development of robust linkages, particularly in light of the seemingly limited utility of an alliance.

\section{Forging Salafi Jihadist alliances}

A survey of the literature reveals that Al-Qaeda has undergone a dramatic transformation in recent times. Beginning in the 1990s, Al-Qaeda has actively sought to expand its international 
reach by building alliances with militant Islamist groups around the world. The decentralization of the movement gathered momentum in the post-9/11 era following the removal of the Taliban regime and Al-Qaeda's loss of sanctuary in Afghanistan. Today, Al-Qaeda prides itself on being a global franchise that brings together a heterogeneous constellation of disparate groups based as far afield as Indonesia, and Yemen. Indeed, some argue that the Al-Qaeda network consists of an "umbrella of 30-40 Asian, African, Middle Eastern groups," ${ }^{, 6}$ while others note that the group has cells in nearly 70 countries. $^{7}$ Similarly, ISIS has dramatically expanded its international reach recently and notable Jihadists such as Nigeria's Boko Haram, Libya's Ansar al-Sharia and Egypt's Supporters of Jerusalem, have publicly declared allegiance with ISIS. Indeed, 60 Jihadist organizations in nearly 30 countries had reportedly pledged support to ISIS by November $2014 .^{8}$

While Al-Qaeda and ISIS have formed ever expanding strategic ties with local Islamists, it is worth noting that these relations are very heterogeneous in character. Much of the discussion that follows is based on the tremendous diversity that exists within the set of formal and informal alliances that Al-Qaeda has cultivated. As the ISIS led network is still in its formative stages, the scarcity of reliable academic sources precludes a careful examination of intra-network variations with regard to ISIS.

Scholars posit that the Al-Qaeda franchise can be divided into several tiers. Some groups have formally merged with the Al-Qaeda core based in Pakistan. They take direct orders, consult closely with Al-Qaeda and some have even absorbed the Al-Qaeda name. Examples include the Yemen based Al-Qaeda in the Arabian Pennisula (AQAP), Al-Qaeda in the Islamic Maghreb (AQIM), Al-Nusra in Syria and Al- Shabaab in Somalia. ${ }^{9}$ Numerous other Jihadist movements, while not formally affiliated with the Al- Qaeda core, have shared informal ideological and operational ties with the group. Examples include Ansar-al-Sharia in Libya, Lashkar-e-Taiba in Pakistan and Jemaah Islamiyah in 
Southeast Asia. ${ }^{10}$ Similarly, others, like the western China based East Turkestan Movement (ETIM) and the Abu Sayyaf Group in the Philippines have developed loose, periodic affiliations with AlQaeda. $^{11}$

There are also several instances of affiliate-affiliate relations within the Al-Qaeda network. For example, AQAP and Al-Shabaab are believed to have extensively cooperated with each other. ${ }^{12}$ Similarly, AQIM and Al-Qaeda in Iraq (AQI) cultivated significant linkages in the early 2000s. ${ }^{13}$ Further, AQIM has forged operational/ideological ties with several African groups including Boko Haram and the Mali based Ansar-Dine. ${ }^{14}$

Some groups like the Libyan Islamic Fighting Jihad (LIFG) and the Egyptian Gamaat alIslamiyya developed strategic partnerships with Al-Qaeda and subsequently withdrew from them for a variety of reasons. ${ }^{15}$ Two groups based in the restive southern Philippines, the Moro Islamic Liberation Front (MILF) and the Abu Sayyaf Group have increasingly diminishing connections with transnational Jihadists. ${ }^{16}$

The above discussion has provided a microcosm of the diversity in relations between Islamist militants. However, some Jihadist groups are characterized by a complete absence of ties with transnationals like Al-Qaeda or the evidence of linkages is extremely inconclusive. These include prominent exemplars such as Hamas and the Muslim Brotherhood, ${ }^{17}$ but, also, multiple insurgency movements in the Muslim dominated southern Thailand, ${ }^{18}$ the ADF in the Ugandan- Congolese border and several Salafi Jihadist movements in the Gaza Strip. ${ }^{19}$ It is this set of cases that underpins the research question motivating this study: what explains the absence of bonds between certain Jihadist movements?

\section{Rationale for case selection}


The case of the Allied Democratic Forces (ADF) is used to illustrate why militant Islamist linkages are elusive at times. There is little credible evidence that the ADF has forged meaningful ties with foreign Islamist militants in spite of the Ugandan government's intermittent allegations of the ADF developing ties with Al-Qaeda and Al-Shabaab. ${ }^{20}$ The ADF was chosen as the case study for several reasons. First, there is growing attention on Islamic militancy in Africa, particularly with rising Jihadi activity in countries such as Mali, Libya and Algeria and the growing notoriety of groups like Boko Haram and Al-Shabaab. Alexander suggests that the proliferation of Jihadist movements across Africa has created a "trans-Saharan arc of instability." ${ }^{21}$ Some have dubbed the continent "Afrighanistan," implying that parts of Africa are becoming a fertile breeding ground for Jihadi terrorism. ${ }^{22}$ Further, several of the African groups have formed a string of operational and ideological ties with regional Islamist militants. ${ }^{23}$ Indeed, the focus on the ADF is especially warranted given Al-Shabaab's deepening connections with Islamist militants in Kenya. ${ }^{24}$ Such ties have fueled fears that the group may attempt to expand its links across East Africa, particularly given Al-Shabaab's previous history of conducting terrorist attacks on Ugandan soil. ${ }^{25}$ Given this context, the dearth of substantiated links between the ADF and other Islamists makes the group an intriguing anomaly and worthy of further exploration.

Second, the ADF operates in an environment similar to where inter-Jihadi ties have flourished in Nigeria, Somalia, Libya and Mali. Specifically, it is based in an area characterized by weak central government authority, porous boundaries and rugged terrain. Such conditions can often be conducive to the development of militant linkages. ${ }^{26}$ The ADF, in fact, has capitalized on such factors and formed sporadic alliances with several rebel outfits in the DRC. ${ }^{27}$ However, crucially, not one of these partnerships has been with a militant Islamist group. 
Third, it is opportune to study the ADF more closely as the group has increasingly been in the spotlight recently. After being quiescent for some time, the ADF carried out a series of devastating attacks on civilians in the DRC over the last two years and became embroiled in sustained fighting with the Congolese army. ${ }^{28}$ Furthermore, the group has been accused of killing Muslim clergy members in Uganda in early 2015. ${ }^{29}$ This recent escalation in ADF militancy has reignited interest in the group and raised questions whether the surge in violence is linked to assistance/influence from other Jihadist groups.

\section{Theorizing terrorist networks}

Before addressing why the ADF has not cultivated linkages with other militant Islamists, it is imperative to engage in a theoretical discussion on the nature of terrorist alliances. Two questions, in particular, are salient: 1) why do terrorist networks develop in the first place and 2) what factors could possibly account for the diversity in alliances between terrorist groups?

A strategic partnership between a locally based militant Islamist group and a transnational Islamist movement is more likely when there is a symbiotic relationship between partners. Both parties may gain from ideological congruence, aggregation of resources/capabilities and operational specialization, among others. ${ }^{30}$ The following discussion explores the specific parameters of this synergy.

\section{Benefit to transnational Islamists}

Groups like Al-Qaeda encourages supporters to wage a holy Jihad against those that it perceives as enemies of Islam. Specifically, the United States and other Western allies are believed to be a waging a global conspiracy against Islam with the aim of marginalizing the 
wider Muslim community. ${ }^{31} \mathrm{Al}$ Qaeda needs to expand its global franchise for myriad different reasons. First, affiliation affords Al-Qaeda an excellent opportunity to propagate its doctrine to an ever wider audience. ${ }^{32}$ Second, as Al-Qaeda's ideology reaches a wider audience, there has been an increase in affiliate groups willing to carry out acts of Jihad, at local, regional and global levels. ${ }^{33}$ In particular, some affiliates have shown an increasing propensity to target Western interests. ${ }^{34}$ Third, in a post 9/11 context, with Al-Qaeda at the receiving end of stringent and ongoing counter-terrorism measures, the group increasingly found itself under siege. In this context, alliance building has enabled the group to sustain its mission and to a certain extent, its operations. ${ }^{35}$ Fourth, cultivating strategic partnerships is crucial given Al-Qaeda's lack of popular support amongst the wider Muslim community. For instance, polling data collected by the Pew Global Attitudes Survey in seven Muslim majority countries from 2003-2009 showed a clear trend in declining public confidence in Osama bin Laden. ${ }^{36}$

Linkages with local groups provide global Jihadists bases to take sanctuary in. Studies on militant activity in Pakistan indicate that Al-Qaeda received various levels of assistance from local militant groups. One group in particular, Lashkar-e-Taiba, provided safe houses and was active in facilitating Al-Qaeda movement in Pakistan. ${ }^{37}$ Similarly, Jemaah Islamiyah received sanctuary from local militants based in the southern Philippines as the Indonesian and Malaysian governments intensified their crackdown in line with the US led global campaign against terrorism. ${ }^{38}$

\section{Benefit to local Islamists}

Local militants benefit from accreditation with transnational groups through the training of combatants, emulation of tactics and the provision of financial and logistical support. A 
number of Al-Shabaab training camps in Somalia were conducted by foreigners with close connections to Al-Qaeda. ${ }^{39}$ In a similar vein, Lashkar-e-Taiba, AQAP and Boko Haram militants received training in camps controlled by Al-Qaeda or affiliates. In such camps, local militants are instructed on strategies ranging from suicide bombing to guerilla warfare and exposed to sophisticated weaponry, which often leads to the transplanting of such tactics in the local theatre. ${ }^{40} \mathrm{Al}$-Qaeda's vast recruitment network has also enabled local Jihadists to attract foreign fighters to their cause. ${ }^{41}$ In some cases, local militants team up with foreign Jihadists when they face setbacks such as military defeat or loss of recruitment and thus, in need of fortification. ${ }^{42}$

Numerous local Islamists have received financial and logistical assistance from foreign Jihadists. Examples include Al-Qaeda's financial inducements to Al-Shabaab, the Egyptian Islamic Jihad, the MILF and the Abu Sayyaf Group. Similarly, Al-Qaeda's formal affiliate, AQIM, has rendered financial assistance to several local Jihadist groups in Africa including Boko Haram and Ansar Dine. ${ }^{43}$

As a locally based militant group waging parochial battles, its salience is often confined to its own operating sphere. Hence, banding together with Al-Qaeda and "officially" becoming a part of the global franchise gives them an almost irresistible lure through greater name recognition. The Algerian based Salafist Group for Preaching and Combat (GSPC) officially changed its name to Al-Qaeda in the Islamic Maghreb (AQIM) in early 2007. It was believed that a name change could reinvigorate its militant base, enhance its legitimacy amongst radical Islamists internationally and bring greater "prestige" to the group. ${ }^{44}$

\section{Variation in the strength of Jihadi alliances}


As previously noted, there is tremendous variation within the set of formal and informal alliances that Islamist militants have formed with each other. Further, some groups have subsequently ended up retracting linkages. Such variation in outcome is an intriguing empirical puzzle and this section aims to hypothesize conditions that could shed light on the differing strength, scope and patterns of terrorist networks.

\section{Ideological incongruence}

It is evident that the Salafi Jihadist movement comprises a range of ideological opinions open to multiple interpretations. Clear fissures have emerged on several issues and such divisions have often contributed to the disparate nature of alliance patterns. ${ }^{45}$ One issue of contention is the identification of the primary target for Jihadists, encapsulated in the "far enemy vs. near enemy" debate. Global Jihadists like Al-Qaeda focus primarily on the "far enemy"- United States and other Western countries deemed to be responsible for the marginalization and persecution of Islam. In contrast, local Salafi Jihadists are often preoccupied with the "near enemy" - apostate regimes in their own region. While Osama bin Laden and Ayman al-Zawahiri stressed on the importance of making "America bleed," local Islamists are more concerned with battling unIslamic governments in their own neighborhood. ${ }^{46}$ This tension, has obstructed Al-Qaeda from forging closer ties with Boko Haram, Lashkar-e-Taiba and Ansar-Dine as these groups consider Nigeria, India and Mali (rather than the United States) respectively as their primary adversary. ${ }^{47}$ There is also much disagreement on the extent of Islamic governance that Jihadists envision. AlQaeda seeks to establish a global Islamic caliphate that unites Muslims in Asia, Africa, Europe and the Middle East. Other Jihadi groups espouse less expansive ambitions; ISIS has declared a 
caliphate in parts of Iraq and Syria, Boko Haram in northeastern Nigeria and Ansar al-Sharia (Libya) aims at Islamic governance in Libya. ${ }^{48}$

One of the more pressing ideological issues for Salafi Jihadists is the takfir question who is a "real" Muslim? Secular regimes in Muslim majority countries, apostates and heretics are often branded as unbelievers by radical Islamists. ${ }^{49}$ The designation of co-religionists as unbelievers has grave implications on how victims/targets are selected and has caused dissension within the Jihadi fraternity. ${ }^{50}$ Hardcore Jihadists like Al-Qaeda advocate a more extreme takfir position. For example, they excoriate Shia Muslims as unbelievers for what they consider to be irreconcilable theological differences and advocate violence against the latter. This is in stark contrast to groups such as the Muslim Brotherhood that staunchly champion Muslim unity and oppose dissecting intra-religious differences. ${ }^{51}$

A more uncompromising stance on the takfir issue can widen a group's likely target base and increases the possibility of violence on other Muslims and civilians. However, it threatens a group's actual and potential alliances with other militants as the more moderate Jihadists balk at the likelihood of violence against civilians. Local Jihadists in Chechnya and southern Thailand as well as the LIFG in Libya rejected closer cooperation with Al-Qaeda owing to the latter's deliberate targeting of civilians. ${ }^{52}$ In some cases, the Al-Qaeda core has also been concerned about the excessively violent tendencies of certain affiliates and urged groups such as the AQI and the Pakistan Taliban (TTP) to be more discriminate in target selection. ${ }^{53}$ Moderate Salafi groups such as the Muslim Brotherhood rejects violence "outside of carefully defined domains" and has unequivocally denounced the $9 / 11$ attacks as well as other violent incidents carried out by Al-Qaeda and affiliates. ${ }^{54}$ 
The extent of engagement with existing political institutions has also caused discord amongst Jihadists. Al-Qaeda's ambitions of creating a global Islamic caliphate that transcends prevailing state boundaries is clearly at odds with various local Jihadists that situate their struggle within the nation-state and show willingness to engage with the existing national government. ${ }^{55}$ Further, radical Salafi Jihadists seek to replace democracy with Sharia law. Hence, movements such as Hamas and the Muslim Brotherhood are roundly berated for participating in elections and the broader political process. The Brotherhood's strategy of attempting to effect change by working within existing institutions is anathema to Al-Qaeda's preferred vision of repudiating the prevailing political system. ${ }^{56}$

\section{Degree of salience to the local community}

Studies suggest that the durability of an alliance between global and local Jihadists is conditional on how such a partnership resonates with the local population. As Byman observes, preference diversion obstructs meaningful Jihadi linkages. ${ }^{57}$ In the Gaza Strip, many local Jihadists place importance on attacking internet cafes and video stores that they perceive as symbols of impurity. While Al-Qaeda may share this sentiment in general, such targets are not a high priority for them. ${ }^{58}$ Conversely, Al-Qaeda's preoccupation with issues like the Danish cartoons that mocked Prophet Mohammed did not hold the same level of importance to Iraqi Jihadists more concerned with local issues. ${ }^{59}$ Haynes argues that a sustained nexus between local and foreign Islamists is unlikely in the East African region. For centuries, East African Muslims have been apolitical (in matters of religion) and followed a "relatively liberal and mystical brand of Islam" far removed from the radical version championed by global Jihadists. 
Even in Muslim majority Zanzibar, with its litany of grievances, groups that seek a more Islamic agenda have chosen to do so through negotiation and discussion. ${ }^{60}$

Embracing a more global agenda represents an opportunity cost for local militants in that it takes away resources that could be devoted towards more parochial objectives. This, in turn, can lead to cracks in the Jihadi network. For instance, while participation in elections might threaten the ideological purity of global Jihadists, local Jihadists perceive them as a gilt-edged opportunity to defend and better their communities. ${ }^{61}$ Similarly, tensions arose within AlShabaab and Ansar Dine, as factions in each group sought to maintain dialogue and engagement with their respective national governments in spite of pressure from $\mathrm{Al}$-Qaeda and AQIM to sever ties. ${ }^{62}$ Groups such as AQAP and Al-Nusra became more cognizant of the need to continue the provision of social services to locals to secure their support even as they came under increasing influence from foreign Islamists with different priorities. ${ }^{63}$

Partnership with global Jihadists can attract more foreign fighters to a local cause; however their strict adherence to a global agenda and lack of familiarity with indigenous mores can estrange local supporters. The presence of foreigners in the higher echelons of Al-Shabaab and forced marriages to foreign fighters were resented by many Somalis ${ }^{64}$ Puritanical practices of foreign Islamists often leading to the brutalization of the local Sufi population and the destruction of venerated cultural symbols were deeply despised by local communities in Mali, ${ }^{65}$ Afghanistan ${ }^{66}$ and Somalia. ${ }^{67}$

Issue salience is also pertinent for the Al-Qaeda core. Affiliation poses the risk of contaminating Al-Qaeda's ideological brand as the group wrestles with the diverse agendas of local Jihadists. Two cases from the southern Philippines are instructive. First, the Abu Sayyaf Group increasingly fell out of favor with Al-Qaeda as the former changed its focus from 
embracing global Jihad to banditry and criminal activity. ${ }^{68}$ Second, the MILF's continued dalliance with the infidel Philippine state proved ideologically unpalatable to Al-Qaeda. ${ }^{69}$

For a Jihadist relationship to be robust, a balance has to be struck between global and

local agendas. The AQAP has seemingly balanced this dual agenda better than most. ${ }^{70}$ It has done so by carrying out high profile attacks abroad while at the same time being able to effectively channel local grievances. The group has emphasized the inviolable sanctity of tribal land, played on longstanding tribal fears of outside influence and used such notions to justify their attacks. ${ }^{71}$ Further, as Loidolt notes, AQAP has categorically linked its goals to widely held grievances against the Yemeni government; namely, corruption, political oppression and its lack of Islamic credentials. Such strategic "packaging" of its agenda has enabled the group to maintain salience amongst the local population. ${ }^{72}$

\section{Fear of attracting new enemies}

One notable downside of cultivating visible links with global Jihadists is that local Islamists could attract considerable scrutiny from law enforcement authorities. Particularly, in the midst of a concerted global campaign against terrorism, conspicuous ties with groups such as Al-Qaeda or ISIS increase the possibility of a local Jihadist group being subject to more stringent counter-terrorism measures. The likelihood of attracting new adversaries may serve as a deterrent as local groups ponder the pros and cons of a transnational alliance. ${ }^{73}$

Some sources suggest that Al-Shabaab delayed officially aligning with Al-Qaeda as it feared more attention from Western counter-terrorism organizations. ${ }^{74}$ Declassified documents captured from the Abbottabad raid that led to the death of bin Laden suggests that the former AlQaeda leader discouraged Al-Shabaab from a formal union as it would encourage greater 
"enemy" mobilization against Somalia. ${ }^{75}$ AQIM's formal affiliation with Al-Qaeda expedited American led military operations against the group and also encouraged greater security cooperation between Algeria and Morocco. ${ }^{76}$ Similarly, as AQAP became closer to Al-Qaeda, the group was designated as a Foreign Terrorist Organization (FTO) by the US State Department and as an Al-Qaeda connected entity by a UN Committee established pursuant to the Security Council Resolution $1267 .{ }^{77}$

Even limited, unverified or inconsistent linkages with global Jihadists may put local Islamists at risk. Arab financial assistance to Islamist militants in Chechnya was depicted as an extension of Al-Qaeda's global Jihad by Russian President Putin. ${ }^{78}$ Likewise, Al-Qaeda's sporadic ties to the ETIM led Uighur separatists in China allowed the Chinese government to frame its security operations in the region as part of the global war on terror. ${ }^{79}$

In summation, the foregoing discussion suggests that linkages between foreign and local Islamists are more likely when the relationship is symbiotic in nature and confers benefits to both sides. The literature indicates that multiple factors such as the extent of disagreement on a range of ideological issues, the degree of relevance to the local community and potentially attracting more attention from counter-terrorist operatives are helpful in explaining variations in the scope and depth of Jihadi relations. As the following section engages in a detailed examination of the Allied Democratic Forces (ADF), the above theoretical discussion is useful for understanding why inter-Jihadi linkages are less likely in some cases.

\section{Case Study: Allied Democratic Forces (ADF)}

Origins and timeline 
The ideological roots of the ADF grew in the 1980s in central Uganda as a response to the Ugandan government's perceived discrimination of its Muslim population. ${ }^{80}$ The precursor to the ADF was the Ugandan Mujahidin Freedom Fighters, an armed group instituted by The Islamic Salaf Foundation and composed mainly of members of the puritanical Tabligh sect. ${ }^{81}$ Sect members recruited militants through a well-organized network to protest the marginalization of Muslims. A controversial decision by the Ugandan Supreme Court in 1992 to rule in favor of a rival Muslim group further radicalized the Tabligh movement. ${ }^{82}$ They retaliated violently, fled to western Uganda and engaged the Ugandan military in sustained fighting. After a series of defeats, the Tabligh retreated to the DRC, from where they established the ADF in 1996, under the leadership of Jamil Mukulu. ${ }^{83}$

While the ADF's origins are in central Uganda, the group's principle theatre of operations has long been the Rwenzori mountainous region that straddles western Uganda and the eastern DRC. ${ }^{84}$ The group's presence in this region is far from coincidental. The distinctive characteristics of the Rwenzori borderland presented the ADF with multiple opportunities. Weak central government control on either side of the border allowed the ADF to carry out attacks with impunity and exploit opportunities for collusion with other rebel groups embroiled in the wider Congolese war. Moreover, similar cultural traits and a tradition of cross-border interaction hastened the development of transnational networks. ${ }^{85}$

Further, the region has a long history of contentious mobilization, largely due to the efforts of the Rwenzururu Resistance Movement. The movement fought against the colonial administration and several Ugandan governments for political autonomy and declared a secessionist kingdom in the region in 1962. While a political settlement was enacted in the 1980s, some factions within the movement were disgruntled at the extent of political change and 
resumed armed struggle. One such faction established the National Liberation Movement for Uganda (NALU) in the late 1980s and fled to the DRC following military defeat by the Ugandan army. ${ }^{86}$

In 1996, NALU formed an association with the ADF in the city of Beni in eastern DRC. Several common denominators united the two groups; distrust of the Ugandan regime of Yoweri Museveni, their presence on Congolese soil and external support provided by the Sudanese and Congolese governments. ${ }^{87}$ The ADF-NALU partnership carried out numerous attacks in the 1990s; conservative estimates indicate that over 1,000 people were killed and over 100,000 displaced from 1996-2001. ${ }^{88}$ Prominent targets included police stations, administrative buildings and schools. The campaign of terror spread fear through the civilian population and torpedoed the economy. According to some estimates, tax revenue dropped dramatically and the ubiquitous presence of landmines undermined agricultural productivity. ${ }^{89}$

The Ugandan military sought consent from the Kabila regime in the DRC and deployed troops across the border in 1998 to combat the ADF threat. Multiple leaders were killed or captured and the movement was largely destabilized by 2002. The rebels retreated deeper into the DRC and the departure of the Ugandan troops in 2003 allowed the ADF-NALU alliance to regroup through vigorous recruitment. The next few years were punctuated by intermittent attacks by the ADF and military offensives launched by the Ugandan army, Congolese army and the UN Mission in the DRC (MONUC). In 2007, the ADF lost its NALU component as the latter surrendered and acquiesced to a political settlement with the Ugandan government. ${ }^{90}$

After a period of relative dormancy, interspersed with occasional bouts of violence, ${ }^{91}$ there has been a significant resurgence in ADF activity over the last two years. A series of devastating attacks on civilians in the eastern DRC has been blamed on the ADF. ${ }^{92}$ Moreover, 
Operation Sukola I, launched against the ADF by the Congolese army and the UN Mission in the DRC (MONUSCO) ${ }^{93}$ in January 2014, has also escalated the level of violence. ${ }^{94}$ Human Rights Watch estimates that 175 civilians were killed in Beni in the last three months of 2014 and a report by the United Nations Office of the High Commissioner for Human Rights reveals rampant abuses by the ADF including executions, kidnappings, abduction of children, rape and the systematic destruction of property. ${ }^{95}$ Moreover, there have been reports of attacks inside Uganda, including the alleged assassinations of Muslim clergy members in early $2015 .{ }^{96}$ While there is absolutely no doubt that the level of violence unleashed by the ADF against civilians has dramatically escalated in the last two years, some analysts caution that it is not clear whether the group alone is responsible for all attacks in the Beni area given the presence of other militant groups in the region. ${ }^{97}$

The ADF suffered several battlefield defeats in 2014 and the militants were dislodged from several bases in North Kivu and forced to flee into the forest. It is reported that the ADF fragmented into smaller groups to improve their chances of avoiding detection from the advancing Congolese forces. ${ }^{98}$ Many senior commanders of the ADF are still missing; however, after a protracted search, ADF's leader, Mukulu, was arrested by the Tanzanian police in Dares Salaam in April 2015. At the time of writing, a Tanzanian court has just cleared Mukulu's extradition to face trial in Uganda on multiple charges of incitement of violence. ${ }^{99}$

\section{Ideology and motivations}

ADF's inception can be traced to a core group of puritanical Muslims from the Tabligh movement. The Salaf sect is considered to be part of the Tabligh and it is alleged that the ADF is mainly made up of Salafi Muslims. ${ }^{100}$ ADF's leader, Mukulu, is a strong adherent of Salafi 
Islam and has indicated his desire to overthrow the government of Uganda and establish an Islamist state based on Sharia law. The ADF has distributed incendiary tape recordings of Mukulu that urge followers to wage a holy Jihad, carried out forcible conversions of nonMuslims and meted punishments in accordance with Islamic law. However, as discussed later, the importance of Islamic ideology to the group as a whole is a matter of contention. ${ }^{101}$ The ADF is often described as a "rebellion without a cause." The group has no clear-cut political program and its goals are open to debate.

\section{Recruitment, financing and networks}

$\mathrm{ADF}$ has a far-reaching recruitment network that has managed to withstand repeated offensives by the Ugandan, Congolese and UN authorities. The ADF resorts to both voluntary and involuntary recruitment. Voluntary recruitment methods include personal invitations by existing members of the group and the use of Muslim clerics to encourage recruitment at mosques and schools. Many combatants also join willingly out of political frustration or a lack of viable alternatives. Involuntary recruitment is pursued in the form of abductions and luring people through false promises of free education, employment and business opportunities. ${ }^{102}$ The group has also recruited a considerable number of child soldiers. ${ }^{103}$ In the late 1990 s, at its peak, ADF-NALU cadres numbered an estimated 4,000-5,000. ${ }^{104}$ According to Ugandan authorities and UN sources, the ADF had an estimated strength between 1,200 and 1,500 fighters in late 2013. ${ }^{105}$ This drop in numbers is partly attributable to the breakup of the ADF-NALU alliance in 2007 and is also influenced by recent military offensives in the Rwenzori borderland.

The ADF has access to multiple sources of financing. The group maintains an extensive business network mainly concentrated in Congolese towns such as Butembo, Beni and Oiche in 
North Kivu, but also extending to areas in Uganda and Rwanda. The militants rely on this network for funding, cross-border trading and the timely provision of material support such as food, clothing and medicine to ADF training camps. ${ }^{106}$ Businesses controlled by the ADF range from pharmacies to motorcycle taxi companies and to stores selling a variety of retail goods; such interactions make it easier for the group to embed itself in the local economy. ${ }^{107}$ Some ADF members engage in agricultural activity and trade their produce in the local market. ${ }^{108}$ The harvesting of timber and coffee in areas of control is a particularly lucrative avenue of raising funds. The group has in place an elaborate system of taxation for those who harvest timber. The aforementioned business networks are often instrumental in illegally exporting timber and coffee to Uganda. Some sources also suggest that the ADF has controlled small gold mines in the area. ${ }^{109}$ Moreover, the movement allegedly receives funding through international money transfers from Kenya, Tanzania and the UK. ${ }^{110}$

In its early years, the ADF obtained substantial financial and logistical assistance from the Sudanese government and the Congolese regime of Mobutu. The Sudanese government has a long history of supporting rebel groups attempting to overthrow the Museveni regime in Uganda, mainly as a response to the Ugandan government's support of the secessionist Sudanese People's Liberation Army (SPLA). Hence, Sudan's support of the ADF was fairly predictable in this context. ${ }^{111}$ As for Congolese support, Mobutu extended sanctuary and other forms of support to the ADF such as military equipment and intelligence as the movement represented a "counterforce to the growing Rwandan-Ugandan collaboration against Hutu militias in eastern Congo."112

\section{$A D F$ in the context of the greater Congolese conflict}


The wider Congolese conflict, popularly known as the Great Lakes Crisis, is actually the combination of a number of conflicts. The first began with the arrival of Rwandan Hutu after the Rwandan genocide in 1994, an event that disrupted already tenuous relations between Congolese ethnic groups. With the influx of two million refugees in the span of a few months, local conflicts over land exacerbated and ethnic groups mobilized around those most similar, creating a zero-sum situation where defeat was akin to a death sentence. To compound matters, the instability in the1990s occurred during a period of political turbulence in the DRC. The toppling of Mobutu in 1997 and his replacement by the Kabila regime prolonged the climate of political volatility. This was a period when fighting intensified, especially between Congolese Hutu and Rwandan Hutu, in addition to ongoing skirmishes between various ethnic groups such as the Mende and Hima in the North and South Kivu regions that bordered Rwanda and Uganda. By this time, the fighting had gone beyond ethnic conflict and involved localized political, economic and military motivations and attracted fighters from neighboring states, and some from as far away as South Africa and Libya. ${ }^{113}$

The emergence and entrenchment of the ADF in the Rwenzori borderland has to be considered in the context of the above geopolitical crises. Before long, the ADF-NALU alliance became "part and parcel of a growing regional war complex." 114 The increasing lack of state control in eastern Congo expanded the geographic space available to the ADF. The multitude of armed actors on the ground led to constantly shifting alliances and provided the ADF with scope to forge opportunistic alliances with various armed groups in the region such as the Hutu Interahamwe and the Mai-Mai militias. ${ }^{115}$ Such coalitions were motivated at times by practical reasons and at other times by political imperatives. ${ }^{116}$ 


\section{Explaining ADF's lack of ties with other Islamists}

As discussed earlier, whether or not a relationship develops and sustains between Islamist militant groups is predicated on several factors. These include the extent of ideological divergence, degree of relevance to the local community and the fear of attracting new enemies. In the case of the ADF, each of these factors is highly relevant in understanding why meaningful ties between the group and other Jihadists have not materialized.

\section{Importance of Islamic ideology in the ADF}

The ADF is associated with the Salaf Tabligh sect and often labeled as a militant Islamist movement by the Ugandan authorities. Moreover, many academic and policy reports also describe the ADF through a primarily Islamist lens. ${ }^{117}$ As previously mentioned, Mukulu is a strong adherent of Salafi thought and has expressed his desire to establish an Islamist state in Uganda. The 2015 report by the UN panel of experts on the DRC reveals that the ADF carried out Islamic instruction in its training camps, utilized a legal system based on the Koran and forcefully converted its abductees to Islam. Indeed, failure to convert was often punishable by death. ${ }^{118}$ Moreover, Hellyer observes that Muslim women in the ADF camps that she visited increasingly wore more conservative attire. ${ }^{119}$

The above description provides a brief snapshot of the Islamic character of the ADF. However, Scorgie-Porter argues forcefully that an exclusive focus on the religious aspect provides a limited and inaccurate account of the group's motives and strategies and neglects other strands important to the development of the ADF. She questions the salience of Salafi ideology to the organization in general and observes that "ADF camps have been Islamicized to different degrees." 120 
Some suggest that the group was mainly driven by a political agenda of removing the Museveni regime and used its Islamic identity instrumentally. A former ADF militant interviewed by Hovil and Werker contended that "the agenda of the ADF was purely political...the ADF adapted the grievances of Islam in order to appeal to these people. Islam was a ticket, so the leaders disguised their political motives in religion." 21 Titeca and Vlassenroot resist reducing the role of Islam to instrumental usage, but suggest that the religious reference coexisted with other agendas such as regime change. Further, they contend that the movement's agendas have changed over time, possibly influenced by its long sojourn in the DRC. For instance, during recent peace talks, the principal ADF demands revolved around socioeconomic issues such as reintegration of demobilized soldiers rather than effecting regime change or Islamic governance. ${ }^{122}$

In a similar vein, the ADF has been described as a multi-layered entity comprising several different elements with varying agendas. While the Tabligh network has served a vital role in recruitment and was largely responsible for securing funds from multiple Islamic charities and foreign countries during the formative stages of ADF's existence, the group is considerably less reliant on the Tabligh now for recruitment and particularly for funding. Recruitment in the ADF has also been heavily contingent on non-religious factors such as the exploitation of deepseated perceptions of marginalization, poverty and the lack of alternative opportunity in the Rwenzori borderland. As described earlier, ADF's economic embeddedness in the local community provides the group with its primary avenues of funding and material support at present and the group's financial contributions from Islamic sources have considerably dwindled over time. ${ }^{123}$ 
Global Jihadists benefit from a partnership with local Islamists as it affords them the opportunity to export their ideology to a wider audience. Given that less than $10 \%$ of the population is Muslim in ADF's chief operating environment in eastern Congo, it is unclear how foreign Jihadists would benefit from a union with the ADF. Also, the region is populated by a number of militant groups, none of which is fighting to establish Islamist control; making it difficult to develop a following large enough to sustain efforts to establish Sharia Law or encourage global Jihad. Moreover, the ADF's immediate operating environment shows very few signs of radicalization. The group has often recruited from the Muslim communities in Bunia and Beni in North Kivu. Such communities have long interacted with their Muslim counterparts in Kenya and Somalia, yet, there is little evidence of the presence of Muslim extremists in these two towns. ${ }^{124}$ As the Grand Imam of COMICO, a prominent Muslim organization in the DRC observed, "the tolerant nature of the Congolese Islamic faith will reduce the chances of extremist tendencies emerging in the DRC." 125

Ideological disagreements often arise within the Jihadi community over the identification of the primary enemy. The ADF has overwhelmingly favored attacks on the "near enemy" - the Museveni regime in Uganda rather than focusing on the "far enemy" as preferred by global Jihadists. According to data collected by the Global Terrorism Database (GTD), all 37 attacks attributed to the ADF from 2013 to the end of 2014 were carried out in the DRC or Uganda and focused on local targets, in other words, the "near enemy." ${ }^{126}$ Similarly, while some ADF leaders trumpet aspirations of Islamic governance in Uganda, very few concrete steps have been taken in that direction.

Some sources do suggest that elements of Al-Qaeda had sporadic ties with the ADF in the 1990s and provided some financial assistance. ${ }^{127}$ Reportedly, bin Laden even met Mukulu 
while they were both in Sudan in the early 1990s. ${ }^{128}$ Similarly, there has been occasional correspondence with Al-Shabaab operatives. However, such ties have been infrequent and it is likely to remain that way unless the movement displays a greater willingness to act on behalf of an explicit Jihadist agenda.

Mukulu's tape recorded sermons are often inflammatory and lash out at the Ugandan and Western governments. In one such recording, he railed, "Let curses be to Bush, Blair, the president of France and more curse goes to Museveni and all those fighting Islam." In another, he proclaimed that "Muslims should kill non-Muslims, and kill also Muslims who are not fighting for Jihad." 129 Based on Mukulu's interpretation of Sharia law, the ADF has imposed brutal penalties for transgressions. For instance, those attempting to escape ADF camps were beheaded or crucified. ${ }^{130}$ His seemingly hardline position on the takfir issue and penchant for violent retribution could also alienate potential Jihadi partners as they worry about the repercussions of indiscriminately targeting civilians.

It is apparent that a hardcore Salafi Jihadist agenda is not the exclusive focus of the ADF. Not a single attack attributed to the ADF in the last two years has been against the "far enemy" and the group operates in an area with little history of Islamic extremism and littered with a potpourri of insurgent movements with no interest in furthering Jihadist goals. Hence, it is not surprising that the group has not cultivated deep ties with foreign Jihadists. Mukulu's pending extradition from Tanzania and a likely long jail sentence in Uganda will soon necessitate a change in leadership. Unless the new leaders dramatically change course, the present ideological gulf will preclude the ADF from forging meaningful alliances with global and regional Jihadists.

\section{Salience to local community}


Empirical evidence suggests that an alliance between foreign and local Jihadists is more likely to sustain if it resonates with the needs and objectives of the local population. In the case of the ADF, the group has become increasingly integrated with the local community in the eastern Congo and undergone a gradual process of "Congolization." The ADF developed an extensive commercial network that allowed it to exploit the vibrant cross-border informal trade that connects many Ugandan and Congolese communities. This includes the establishment of ties with both Ugandan and Congolese government and military officials to facilitate the transfer of resources out of the DRC and into the regional and, ultimately, global markets. ${ }^{131}$ The relative absence of state control on both sides of the border facilitated free movement of goods and people. In essence, a parallel economy emerged that has maintained the financial viability of the ADF, contributed to the economic life of the region and introduced a semblance of cohabitation between the $\mathrm{ADF}$ and the local population. ${ }^{132}$

Cultural affinity between the Bakonjo in western Uganda and the Banande in eastern DRC allowed ADF fighters to feel "they were within their own community" amongst the Banande. ${ }^{133}$ Moreover, high rates of inter-marriage expedited the pace of "Congolization." In particular, many Ugandan born children of ADF fighters, who fled with their parents to eastern DRC in the 1990s, have married Congolese citizens. ${ }^{134}$ Today, the majority of ADF members are Congolese and it is difficult to conceive of the movement as "Ugandan" or "foreign." 135 Further, the local Muslim community has generally been supportive to the ADF and provided places of worship and opportunities for recruitment and financing. ${ }^{136}$

The prevailing conflict environment in the DRC led to a proliferation of rebel movements in the region; this, allied with the ADF's socio-economic embeddedness in the local community, provided the group with a "bountiful supply of potential partners in crime." 137 While the ADF 
had a prolonged partnership with NALU spanning over a decade, more fleeting collaboration has been reported with multiple other groups including the Hutu Interahamwe, Mai-Mai rebels and the Lendu militia in Ituri. Such tactical alliances developed for a variety of reasons and some even emerged after the formal ending of the Second Congolese War in 2003. ${ }^{138}$

While the ADF did carry out intermittent acts of violence against civilians, the arrangement between the ADF and the local community, at least until 2013, was one of "cooperative (if oftentimes) reluctant coexistence." 139 In general, the ADF respected the "traditional hierarchy of the host communities" and in 2011, was estimated to command "the popular support of nearly half of the population of Beni territory." 140 The intensity of ADF attacks against civilians in eastern Congo has drastically escalated in the last two years. The change in tactics is likely due to a couple of reasons. First, offensive operations against ADF positions have intensified. Buoyed by a series of successful operations against the M23, a group that had occupied the city of Goma for nearly two weeks in late 2012, ${ }^{141}$ MONUSCO and the Congolese army began targeting ADF positions in and around Beni in early 2014. As the ADF suffered heavy losses, the group carried out numerous reprisal attacks on civilian informants alleged to have collaborated with the UN and Congolese forces. ${ }^{142}$ This, in turn, led to the further deterioration of ADF's already uneasy relationship with the local community. Second, as the ADF increased its violence against civilians, local assistance has been harder to obtain and the group has resorted to more coercive and brutal methods to maintain its influence in the region. ${ }^{143}$ As one scholar noted, "people are being punished and killed when they don't want to collaborate" with the ADF. ${ }^{144}$

The foregoing summary of ADF's relations with locals in eastern Congo is important to understand why any potential collaboration between the ADF and foreign Islamist militants is 
unlikely to be welcomed by the local community. As previously noted, preference divergence obstructs the meaningful development of robust ties between local and global Jihadists. Certainly, the preferences of transnational Islamists like Al-Qaeda or ISIS are very differently aligned with those of the ADF. The recent violence against civilians notwithstanding, the ADF still maintains deep-rooted ties with local economic, political and military elites. For instance, elements of the Congolese army are frequently accused of colluding with the ADF in terms of timber trafficking and extorting money from local farmers. ${ }^{145}$ Further, the ADF also maintains ties with political elites, as evidenced by their participation in recent peace talks with the Ugandan government. ${ }^{146}$ Such preferences may be incompatible with global Jihadists such as AlQaeda who tend to avoid any kind of engagement with secular political authorities and worry that involvement in the illicit economy may dilute the ideological purity of their agenda. While the ADF is most definitely not the only Jihadist group to engage in illicit economic activities, this facet, coupled with the group's lack of a coherent religious or political agenda remain significant barriers to preference convergence with global Jihadists.

Preferences of the foreign Jihadists also diverge considerably with those of the civilian masses in eastern Congo. The presence of Islamist foreign fighters with their clarion calls of unleashing a holy Jihad is likely to unnerve the locals in an overwhelmingly Christian region that embraces very different cultural traditions. Civilians may also worry about the maintenance of existing economic networks cultivated over a number of years. Furthermore, ADF's previously manageable ties with the local community have degenerated to unprecedented lows given the group's recent indiscriminate targeting of civilians. In this context, it is unfathomable that the acquisition of a potential partner that may unleash further violence upon civilians would be viewed favorably by the local community. 
Given ADF's history of forging opportunistic ties with militants in eastern Congo, one may wonder whether the group may contemplate a similar dalliance with one or more Jihadist groups active in Africa. Although such a possibility cannot be ruled out, it is unlikely that the relationship would endure, even if it were to emerge. Further, as Scorgie points out, while the ADF interacted with various militant forces in the region, they "by no means 'swallowed' them to make one homogeneous group." The numerous groups operating in the region have been able to maintain their own independent identity, ideology and modus operandi even as they coordinated with each other on attacks and training. ${ }^{147}$ For instance, there is little evidence that the ADF attempted to impose its Salafist ideology on its former colleagues in NALU. In contrast, it is doubtful whether the ADF would be afforded a similar level of autonomy were they to form an alliance with foreign Jihadists given the latter's unrelenting focus on a global agenda.

\section{Fear of attracting new enemies}

Affiliation with global Jihadists is likely to be less alluring to groups such as the ADF, especially given the likelihood of attracting unwanted attention from the international community. The Ugandan government has consistently attempted to link the ADF to global Jihadi groups such as Al-Qaeda and Al-Shabaab. For example, in 2002, Museveni alleged that Al-Qaeda plotted to assassinate him in 1999 via the ADF. He also accused bin Laden of arming the ADF. ${ }^{148}$ In 2005, a top military leader suggested that ADF leader Mukulu was likely to become Africa's next bin Laden. ${ }^{149}$ The government has also claimed that Mukulu was AlQaeda's second in command in East Africa. Partly due to the efforts of the Ugandan government, the United States included the ADF in its "Terrorist Exclusion List" in December 2001, though the group was removed from the list four years later. ${ }^{150}$ Subsequently, in 2011 , the US 
Department of the Treasury designated ADF leader Mukulu as a terrorist in and the same office sanctioned the ADF for its direct targeting of children in 2014. ${ }^{151}$

In spite of the Ugandan government's allegations, little concrete evidence has been uncovered linking the ADF with foreign Islamists. Scholars suggest that Museveni's regime has a vested interest in embellishing real or perceived links between the ADF and foreign Jihadists. First, it allows the regime to deflect attention from its authoritarian tendencies and project itself as a key ally in the US led war on terror; in turn, making it easier to attract American military and diplomatic assistance. Second, exaggerating links also justifies the maintenance of high levels of military spending and gives the government a convenient alibi to continue raids on the eastern DRC where it has a range of interests. ${ }^{152}$

The development of verifiable and more ostensible links with foreign Islamists would no doubt encourage the Ugandan regime to redouble its efforts to portray the ADF as being inextricably linked to global Jihadists. Therefore, from the ADF's vantage point, the fear of attracting new enemies may serve as an effective deterrent against the development of robust linkages, particularly given the limited benefits of an alliance. This also serves to dissuade AlQaeda from aligning with the ADF as it would bring about unnecessary attention to the group in a part of the world where Islam is not as prevalent as in places such as Nigeria, Mali and other cases mentioned above.

\section{Conclusion}

This study has sought to explain the absence of linkages between certain locally based Salafi Jihadist organizations and their larger, more transnational counterparts such as Al-Qaeda or ISIS. In spite of the abundance of empirical literature on Jihadi alliances, the question of why 
inter-Jihadi ties are completely absent or tenuous at times is under-theorized. Given ISIS's recent inexorable advance through the Middle East and North Africa and its ever growing ties with local Jihadists, it is timely to investigate under what conditions locally based militant Islamists are less likely to forge ties with their more transnational counterparts.

This research answers the above question through a detailed examination of the Allied Democratic Forces (ADF). There is little concrete evidence that the ADF has cultivated any substantive linkages with foreign Jihadists. The study posits that the absence of ties is primarily due to three main factors. First, while the ADF retains a nominally Salafi Jihadist outlook, it is clear that Islam is not the exclusive focus of the group. The heterogeneous composition of the ADF has led to the interplay of diverse agendas and motives. The group also operates in a region that is predominately Christian, making it difficult to recruit based on ideological grounds. Moreover, ideological distance on issues such as enemy identification and establishment of Sharia law weakens the likelihood of meaningful ties.

Second, the ADF has become thoroughly immersed in the local Congolese community through a well-developed commercial enterprise and beneficial ties with political and military elites, giving rise to a parallel economy. Cultural similarities and inter-marriage have also facilitated the process of "Congolization." The coexistence between the ADF and the local community has been severely strained in recent times due to indiscriminate acts of violence by the ADF against civilians. Given this context of rapidly worsening ties, an entrenched relationship with transnational Islamists could further aggravate already high levels of tensions and is unlikely to resonate favorably with the local community.

Finally, more verifiable ties with external Islamist militants will likely invite ADF more attention from the Ugandan authorities as well as other regional/global actors. Therefore, the fear 
of attracting new enemies may serve as an effective deterrent against the development of robust linkages. Further, while the ADF is not significant on a global level, it has garnered the attention of regional governments, suggesting the risks of committing resources to the region are not worth the costs for global Jihadists such as Al-Qaeda and ISIS.

${ }^{1}$ Victor Asal, Gary A. Ackerman, and R. Karl Rethemeyer, "Connections Can Be Toxic: Terrorist Organizational Factors and the Pursuit of CBRN Weapons," Studies in Conflict and Terrorism 35(3) (2012), pp. 229-254; Michael C. Horowitz and Philip B. K. Potter, " Allying to kill: terrorist intergroup cooperation and the consequences for lethality," Journal of Conflict Resolution 58(2) (2014), pp.199-225; and Brian J. Phillips, "Terrorist group cooperation and longevity," International Studies Quarterly 58(2) (2014), pp. 336-347.

${ }^{2}$ Rick Nelson and Thomas M. Sanderson, "A Threat Transformed: al Qaeda and associated movements in 2011", (Center for Strategic and International Studies, February 2011); Daniel Byman, "Breaking the Bonds between Al-Qa'ida and Its Affiliate Organizations," Brookings Analysis Paper No. 27, (Brookings Institution, August 2012) and Daniel Byman, "Buddies or Burdens? Understanding the Al Qaeda Relationship with Its Affiliate Organizations," Security Studies 23(3) (2014), pp. 431-470.

${ }^{3}$ For a more detailed discussion see Brynjar Lia, "Jihadi Strategists and Doctrinarians," in Assaf Moghadam and Brian Fishman, ed., Self-Inflicted Wounds: Debate and Divisions within AlQaeda and Its Periphery, (West Point, NY: United States Military Academy, Combating Terrorism Center, 2011), Ch. 5; Daveed Gartenstein-Ross, and Tara Vassefi, "Perceptions of the "Arab spring" within the Salafi-Jihadi movement," Studies in Conflict \& Terrorism 35(12) (2012), pp. 831-48 and Daniel Byman, "Fighting Salafi-Jihadist insurgencies: How much does religion really matter?," Studies in Conflict \& Terrorism 36(5) (2013), pp. 353-71.

${ }^{4}$ Seth G. Jones, A Persistent Threat: The Evolution of Al Qaida and Other Salafi Jihadists (Rand Corporation, 2014), pp. 26.

${ }^{5}$ Caroline Hellyer, "Congo/Uganda: high profile military operations against ADF will not rebuild local stability," African Arguments, October 16, 2014, http://africanarguments.org/2014/10/16/congouganda-high-profile-military-operations-againstadf-will-not-rebuild-local-stability-by-caroline-hellyer/

${ }^{6}$ Rohan Gunaratna, "Ideology in terrorism and counter terrorism: Lessons from combating al Qaeda and al Jemaah Islamiyah in Southeast Asia," in The ideological war on terror: Worldwide strategies for counter-terrorism, ed. A. Aldis \& G.P. Herd, (New York: Routledge, 2007), pp. 33-75.

7 John, Rollins, "Al Qaeda and Affiliates: Historical Perspective, Global Presence, and Implications for US Policy," (Washington DC: US Library of Congress, Congressional Research Service, January 25, 2011).

${ }^{8}$ Riyad Mohammed, "ISIS Beheads Another American as 60 New Terror Groups Join," The Fiscal Times, November 16, 2014, http://www.thefiscaltimes.com/2014/11/16/ISIS-DoublesDown-Infidels-Boosted-60-New-Terror-Groups

${ }^{9}$ Nelson and Sanderson, "A Threat Transformed;" Jones, A Persistent Threat. 
${ }^{10}$ Jessica Ward, "Brand Name Terror: Al-Qaeda Affiliate Organizations and Local Instability," (Honors Program in International Security Studies, Center for International Security and Cooperation, Stanford University, 2013).

${ }^{11}$ Nelson and Sanderson, "A Threat Transformed;

${ }^{12}$ Byman, "Breaking the Bonds," pp. 13.

13 Vahid Brown, "Al-Qa'ida Central and Local Affiliates," in Assaf Moghadam and Brian Fishman, ed., Self-Inflicted Wounds: Debate and Divisions within Al-Qaeda and Its Periphery, (West Point, NY: United States Military Academy, Combating Terrorism Center, 2011), Ch. 4.

${ }^{14}$ Wolfram Lacher, "Organized crime and conflict in the Sahel-Sahara region", The Carnegie Papers (Washington DC: Carnegie Endowment for International Peace, September 2012); Emilie Oftedal, “Boko Haram: A Transnational Phenomenon?' (Master's diss., Department of Political Science, University of Oslo, 2013)

${ }^{15}$ Byman, "Breaking the Bonds."

16 Zachary Abuza, "Borderlands, terrorism, and insurgency in Southeast Asia," in The Borderlands of Southeast Asia: Geopolitics, Terrorism and Globalization, ed. James Clad et al. (Washington, DC: National Defense University Press, 2011), 89-106.

${ }^{17}$ Reuven Paz, "Jihadis and Hamas," in Assaf Moghadam and Brian Fishman, ed., Self-Inflicted Wounds: Debate and Divisions within Al-Qaeda and Its Periphery, (West Point, NY: United States Military Academy, Combating Terrorism Center, 2011), Ch. 8.

${ }^{18}$ Joseph Chinyong Liow, "Local Networks and Transnational Islam in Thailand (with emphasis on the Southernmost Provinces)", in Transnational Islam in South and Southeast Asia: Movements, Networks, and Conflict Dynamics, edited by R.W. Hefner (Seattle, WA: The National Bureau of Asian Research, 2009), 203.

${ }^{19}$ Byman, "Breaking the Bonds."

${ }^{20}$ The Ugandan government's allegations of ADF involvement with global/regional Jihadists remain unsubstantiated. For more, see International Crisis Group (ICG), Eastern Congo: The ADF-NALU's lost rebellion Vol. N 93, (Nairobi/Brussels, 2012); Kristof Titeca and Koen Vlassenroot, "Rebels without borders in the Rwenzori borderland? A biography of the allied democratic forces," Journal of Eastern African Studies 6(1) (2012), pp.154-76 and Daniel Fahey, et al., Final Report of the Group of Experts on the Democratic Republic of the Congo. S/2015/19, (United Nations, 2015).

${ }^{21}$ Yonah Alexander, 'Special update report: terrorism in North, West and Central Africa: from 9/11 to the Arab Spring', (International Center for Terrorism Studies, Potomac Institute for Policy Studies, Arlington, 2012).

${ }^{22}$ The Economist, “Afrighanistan?” January 26, 2013.

${ }^{23}$ See Hans Krech, "The Growing Influence of Al-Qaeda on the African Continent," African Spectrum 46 (2) (2011), 125-137; Oftedal, "Boko Haram: A Transnational;" Matthew J. Thomas, "Exposing and exploiting weaknesses in the merger of Al-Qaeda and Al-Shabaab", Small Wars \& Insurgencies, 24(3) (2013: 413-435).

${ }^{24}$ Christopher Anzalone, "Kenya's Muslim Youth Center and Al-Shabaab's East African Recruitment," West Point (USMA): CTC Sentinel 5(10) (2012): 9-13.

${ }^{25}$ Oscar Gakuo Mwangi, "State Collapse, Al-Shabaab, Islamism, and Legitimacy in Somalia." Politics, Religion \& Ideology 13(4) (2012): 513-527. 
${ }^{26}$ Idean Salehyan, 'Transnational Rebels: Neighboring States as Sanctuary for Rebel Groups," World Politics 59 (2) (2007): 217-242 and Solomon Hussein, "Counter-Terrorism in Nigeria: Responding to Boko Haram,'” The RUSI Journal 157(4) (2012): 6-11

${ }^{27}$ Titeca and Vlassenroot, "Rebels without borders."

${ }^{28}$ Nelson Alusala, et al., Final Report of the Group of Experts on the Democratic Republic of Congo. United Nations, S/2014/42, (United Nations, 2014); Fahey, et al., Final Report of the Group of Experts and United Nations Human Rights Office of the High Commissioner, Report of the United Nations Joint Human Rights Office on International Humanitarian Law Violations by Allied Democratic Forces (ADF) Combatants in the Territory of Beni, North Kivu Province, Between October 1 and December 31, 2014, May 2015, http://www.ohchr.org/Documents/Countries/CD/ReportMonusco_OHCHR_May2015_EN.pdf

29 "Uganda charges 18 for murder of Muslim clerics," January 30, 2015, http://news.yahoo.com/uganda-charges-18-murder-muslim-clerics-115346498.html

30 Byman, "Buddies or Burdens?" Horowitz and Potter, "Allying to kill: terrorist intergroup cooperation."

${ }^{31}$ Gunaratna, "Ideology in terrorism; "Assaf Moghadam and Brian Fishman, "Debates and Divisions within and around Al-Qa'ida," in Assaf Moghadam and Brian Fishman, ed., SelfInflicted Wounds: Debate and Divisions within Al-Qaeda and Its Periphery, (West Point, NY: United States Military Academy, Combating Terrorism Center, 2011), Ch. 1 and Carla Humud, et al., Al Qaeda-Affiliated Groups: Middle East and Africa (Washington, DC: Congressional Research Service, 2014).

${ }^{32}$ Byman, "Breaking the Bonds;" Byman, "Buddies or Burdens?"

${ }^{33}$ Krech, "The Growing Influence," Jeffrey Thomas, Al-Qaeda Affiliates: An Evolving Threat" (Center for the Study of Presidency and Congress, 2011).

${ }^{34}$ Thomas Hegghammer, "The Ideological Hybridization of Jihadi Groups" Current Trends in Islamist Ideology 9 (2009).

${ }^{35}$ Nelson and Sanderson, "A Threat Transformed."

${ }^{36}$ Ibid.

37 Christine Fair, "Militant Recruitment in Pakistan: Implications for Al Qaeda and Other Organizations," Studies in Conflict and Terrorism 27(6) (2004), pp. 489-504.

${ }^{38}$ Abuza, "Borderlands, terrorism, and insurgency."

${ }^{39}$ Thomas, Al-Qaeda Affiliates: An Evolving Threat."

${ }^{40}$ Byman, "Breaking the Bonds;" J. Peter Pham, Boko Haram's Evolving Threat (Africa Center for Strategic Studies, 2012); Ward, "Brand Name Terror."

${ }^{41}$ Byman, "Fighting Salafi-Jihadist insurgencies;" Jones, A Persistent Threat.

${ }^{42}$ Byman, "Breaking the Bonds;" Thomas, Al-Qaeda Affiliates: An Evolving Threat."

${ }^{43}$ Abuza, "Borderlands, terrorism, and insurgency;" Byman, "Breaking the Bonds" and Jacob Zenn, Atta Barkindo, and Nicholas A. Heras, "The Ideological Evolution of Boko Haram in Nigeria: Merging Local Salafism and International Jihadism," The RUSI Journal 158, no. 4 (2013): 46-53.

44 Jean-Luc Marret, "Al-Qaeda in Islamic Maghreb: A 'Glocal' Organization," Studies in Conflict and Terrorism 31(6) (2008), pp. 541-552.

${ }^{45}$ Caitriona Dowd and Clionadh Raleigh, "The myth of global Islamic terrorism and local conflict in Mali and the Sahel." African affairs 112 (448) (2013): 498-509. 
${ }^{46}$ Bruce Hoffman, "Al Qaeda's Uncertain Future." Studies in Conflict \& Terrorism 36(8) (2013), 635-653.

${ }^{47}$ Dowd and Raleigh, "The myth of global."

${ }^{48}$ Byman, "Breaking the Bonds; Hoffman, "Al Qaeda's Uncertain Future."

${ }^{49}$ Mohammed Hafez, "Tactics, Takfir, and anti-Muslim Violence," in Assaf Moghadam and Brian Fishman, ed., Self-Inflicted Wounds: Debate and Divisions within Al-Qaeda and Its Periphery, (West Point, NY: United States Military Academy, Combating Terrorism Center, 2011), Ch. 2.

${ }^{50}$ Byman, "Breaking the Bonds."

${ }^{51}$ Bernard Heykel, "Jihadis and the Shi' a," in Assaf Moghadam and Brian Fishman, ed., SelfInflicted Wounds: Debate and Divisions within Al-Qaeda and Its Periphery, (West Point, NY: United States Military Academy, Combating Terrorism Center, 2011), Ch. 9; Marc Lynch, "Jihadis and the Ikhwan," in Assaf Moghadam and Brian Fishman, ed., Self-Inflicted Wounds: Debate and Divisions within Al-Qaeda and Its Periphery, (West Point, NY: United States Military Academy, Combating Terrorism Center, 2011), Ch. 7.

${ }^{52}$ Liow, "Local Networks and Transnational Islam;" Krech, "The Growing Influence;" Byman, "Breaking the Bonds."

${ }^{53}$ Lia, "Jihadi Strategists" and Nelly Lahoud et al., "Letters from Abbottabad: Bin Ladin Sidelined," West Point Combating Terrorism Center (2012), p. 21.

54 54“"Carefully defined domains" where violence is permissible include Palestinian resistance against Israel and the Iraqi insurgency against the US occupation. For more, see Lynch, "Jihadis and the Ikhwan."

${ }^{55}$ Nelson and Sanderson, "A Threat Transformed."

${ }^{56}$ Lynch, "Jihadis and the Ikhwan;" Hoffman, "Al Qaeda's Uncertain Future."

${ }^{57}$ Byman, "Buddies or Burdens?"

${ }^{58}$ Byman, "Breaking the Bonds."

${ }^{59}$ Ibid.

${ }^{60}$ Jeffrey Haynes, "Islamic Militancy in East Africa," Third world quarterly 26(8) (2005): pp. 1321-1339.

${ }^{61}$ Byman, "Breaking the Bonds."

${ }^{62}$ Dowd and Raleigh, "The myth of global."

${ }^{63}$ Jones, A Persistent Threat.

${ }^{64}$ Anthony Celso, "Al Qaeda Affiliates Operating in Failed States: The Next Front in the War on Terror" (paper presented at Intelligence and Security Informatics Conference (EISIC), 2012).

${ }^{65}$ Lawrence Cline, "Nomads, Islamists, and Soldiers: The Struggles for Northern Mali." Studies in Conflict \& Terrorism 36(8) (2013): 617-634 and Baz Lecocq et al., "One hippopotamus and eight blind analysts: a multivocal analysis of the 2012 political crisis in the divided Republic of Mali" Review of African Political Economy 40(137) (2013): 343-357.

${ }^{66}$ Ward, "Brand Name Terror."

${ }^{67}$ Herman Cohen, "Al Qaeda in Africa: The Creeping Menace to Sub-Sahara's 500 Million Muslims" American Foreign Policy Interests 35(2) (2013): 63-69.

${ }^{68}$ McKenzie O'Brien, "Fluctuations between crime and terror: The case of Abu Sayyaf's kidnapping activities." Terrorism and Political Violence 24(2) (2012): 320-336.

${ }^{69}$ Brown, "Al-Qa'ida Central and Local Affiliates."

${ }^{70}$ Rollins, "Al Qaeda and Affiliates: Historical Perspective." 
${ }^{71}$ Barak Salmoni, Bryce Loidolt, and Madeleine Wells, Regime and Periphery in Northern Yemen: The Huthi Phenomenon (Rand Corporation, 2010), 272-273.

${ }^{72}$ Bryce Loidolt, "Managing the global and local: The dual agendas of Al Qaeda in the Arabian Peninsula." Studies in Conflict \& Terrorism 34(2) (2011): 102-123.

${ }^{73}$ Byman, "Breaking the Bonds."

${ }^{74}$ Brian Bennett, “Al Qaeda's Yemen branch has aided Somalia militants," Los Angeles Times, July 18, 2011.

${ }^{75}$ Lahoud et al., "Letters from Abbottabad."

${ }^{76}$ Cited in Byman, "Breaking the Bonds."

${ }^{77}$ Ward, "Brand Name Terror."

${ }^{78}$ Paul Tumelty, "The Rise and Fall of Foreign Fighters in Chechnya," Terrorism Monitor 4 (January 2006).

${ }^{79}$ Rohan Gunaratna and Kenneth G. Pereire, "An Al-Qaeda Associate Group Operating in China?," China and Eurasia Forum Quarterly 4(2) (2006): 55-61.

${ }^{80}$ Wairama Baker, "Uganda: The Marginalization of Minorities" (UK: Minority Rights Group International, 2001).

${ }^{81}$ International Crisis Group (ICG), Eastern Congo: The ADF-NALU's.

${ }^{82}$ In 1989, the Ugandan Supreme Court adjudged in favor of the Ugandan Supreme Muslim Council -a rival Muslim group- over the leadership of a mosque in Kampala. The decision contributed to the gradual radicalization of the Tabligh sect.

${ }^{83}$ Lindsay Scorgie, "Peripheral Pariah or Regional Rebel? The Allied Democratic Forces and the Uganda/Congo Borderland," The Round Table 100 (2011): 79-93.

${ }^{84}$ International Crisis Group (ICG), Eastern Congo: The ADF-NALU's.

${ }^{85}$ Scorgie, "Peripheral Pariah" and Lindsay Scorgie-Porter, "Economic Survival and Borderland Rebellion: The Case of the Allied Democratic Forces on the Uganda-Congo Border." The Journal of the Middle East and Africa 6(2) (2015): 191-213.

${ }^{86}$ Titeca and Vlassenroot, "Rebels without borders."

${ }^{87}$ International Crisis Group (ICG), Eastern Congo: The ADF-NALU's.

${ }^{88}$ Ibid.

${ }^{89}$ Titeca and Vlassenroot, "Rebels without borders;" "Uganda's Rising Threat: Allied

Democratic Forces,"' Terrorism Research and Analysis Consortium, 2014, http://www.trackingterrorism.org/article/ugandas -rising-threat-allied-democratic-forces-ADF ${ }^{90}$ International Crisis Group (ICG), Eastern Congo: The ADF-NALU's; Titeca and Vlassenroot, "Rebels without borders."

${ }^{91}$ For instance, the Congolese army effected another offensive against the ADF in 2010 and the group stepped up reprisal attacks against both civilian and military targets in the DRC. See "Uganda's Rising Threat."

${ }^{92}$ Scorgie-Porter, "Economic Survival."

${ }^{93} \mathrm{UN}$ Mission in the DRC was renamed as MONUSCO in 2010.

${ }^{94}$ Tom Mueller, "Understanding Eastern Congo's ADF-NALU Rebels," January 29, 2014, http://www.enoughproject.org/blogs/understanding-eastern-congos-adf-nalu-rebels; Fahey, et al., Final Report of the Group of Experts.

${ }^{95}$ Human Rights Watch, World Report 2015: Events of 2014 (Washington DC, 2015); United Nations Human Rights Office of the High Commissioner, Report of the United Nations 96 "Uganda charges 18 for murder." 
${ }^{97}$ Caroline Hellyer, "Beni Massacres and some thoughts on the ADF," Digital Djeli Blog, January 17, 2015. http://digitaldjeli.com/2015/beni-massacres-and-some-thoughts-on-the-adf/; Fahey, et al., Final Report of the Group of Experts.

${ }^{98}$ Fahey, et al., Final Report of the Group of Experts. The report notes that the ADF splintered into two main groups. As the Congolese army approached Madina, the main ADF camp, in April, 2014, one group led by ADF leader Jamil Mukulu fled the camp accompanied by close to 20 other senior leaders. The second group emerged under the leadership of Seka Baluku, Mukulu's second in command, who took over the Madina camp after the former's departure. Baluku group was forced to retreat deeper into the forest in order to evade the pursuing Congolese army.

${ }^{99}$ Nicholas Bariyo, "Tanzanian Court Clears Extradition of Rebel Leader Jamil Mukulu to Uganda," Wall Street Journal, June 25, 2015, http://www.wsj.com/articles/tanzanian-courtclears-extradition-of-rebel-leader-jamil-mukulu-to-uganda-1435252890

${ }^{100}$ Baker, "Uganda: The Marginalization;" Ioannis Gatsiounis, 2012. "After Al-Shabaab," Current Trends in Islamist Ideology 14, pp.74-89.

${ }^{101}$ Titeca and Vlassenroot, "Rebels without borders;" Alusala, et al., Final Report; Fahey, et al., Final Report of the Group of Experts.

${ }^{102}$ Titeca and Vlassenroot, "Rebels without borders;" Fahey, et al., Final Report of the Group of Experts. For more on recruitment patterns, also see, Scorgie-Porter, Lindsay. "Militant Islamists or borderland dissidents? An exploration into the Allied Democratic Forces' recruitment practices and constitution." The Journal of Modern African Studies 53 (1) (2015): 1-25.

${ }^{103}$ Fahey, et al., Final Report of the Group of Experts.

${ }^{104}$ Scorgie, "Peripheral Pariah."

${ }^{105}$ Alusala, et al., Final Report.

${ }^{106}$ Fahey, et al., Final Report of the Group of Experts.

${ }^{107}$ International Crisis Group (ICG), Eastern Congo: The ADF-NALU's;" Alusala, et al., Final Report; Scorgie-Porter, "Economic Survival."

${ }^{108}$ Scorgie-Porter, "Economic Survival."

${ }^{109}$ Titeca and Vlassenroot, "Rebels without borders;" Scorgie-Porter, "Economic Survival."

110 "Uganda's Rising Threat."

${ }^{111}$ Scorgie, "Peripheral Pariah."

112 Titeca and Vlassenroot, "Rebels without borders."

${ }^{113}$ Gerard Prunier, Africa's World War: Congo, the Rwandan Genocide, and the Making of a Continental Catastrophe (New York: Oxford University Press, 2009); Filip Reyntjens, The great African war: Congo and regional geopolitics, 1996-2006 (Cambridge University Press, 2009); Jean-Pierre Chretien and Richard Banegas (eds.), The Recurring Great Lakes Crisis: Identity violence and power (Colombia University Press, 2011).

114 Titeca and Vlassenroot, "Rebels without borders."

${ }^{115}$ Scorgie, "Peripheral Pariah;" Titeca and Vlassenroot, "Rebels without borders."

${ }^{116}$ International Crisis Group (ICG), Eastern Congo: The ADF-NALU's; Alusala, et al., Final Report.

${ }^{117}$ Lindsay Scorgie, "The Allied Democratic Forces: Moving beyond popular narratives," Al Jazeera, July 27,2013 , http://www.aljazeera.com/indepth/opinion/2013/07/201372215812878743.html

${ }^{118}$ Fahey, et al., Final Report of the Group of Experts. 
${ }^{119}$ Caroline Hellyer, “ADF-NALU and Islam, militant and mercenary," Digital Djeli Blog, January 4, 2014 http://digitaldjeli.com/2014/adf-nalu-and-islam-militant-and-mercenary/

${ }^{120}$ Scorgie-Porter, "Economic Survival."

${ }^{121}$ Lucy Hovil and Eric Werker, "Portrait of a Failed Rebellion An Account of Rational, SubOptimal Violence in Western Uganda" Rationality and Society 17(1) (2005): 5-34.

${ }^{122}$ Titeca and Vlassenroot, "Rebels without borders."

${ }^{123}$ Scorgie, "The Allied Democratic Forces" and Scorgie-Porter, "Militant Islamists."

${ }^{124}$ International Crisis Group (ICG), Eastern Congo: The ADF-NALU's.

${ }^{125}$ Caroline Hellyer, "Why are Muslims in the Congo almost invisible?" October 31, 2013.http://muslimvillage.com/2013/10/31/45502/muslims-congo-almost-invisible/

${ }^{126}$ Global Terrorism Database (GTD) of the National Consortium for the Study of Terrorism and Responses to Terrorism shows that the ADF carried out 37 attacks since the beginning of 2013. Most of these were in the DRC with a few attacks in Uganda.

${ }^{127}$ Ibid.

128 "Uganda's Rising Threat."

${ }^{129}$ Titeca and Vlassenroot, "Rebels without borders."

${ }^{130}$ Daniel Fahey, "New Insights on Congo's Islamist Rebels," Washington Post, February 19, 2015.

${ }^{131}$ John Prendergast, Sasha Lezhnev, and Lauren Wolfe, "Suffocating Congo's War." Foreign Policy, February 7, 2015; John F. Clark, Musevini's Adventure in the Congo War: Uganda's Vietnam?, in The African Stakes of the Congo War. John F. Clark (ed) (Palgrave 2002):

International Crisis Group (ICG), Eastern Congo: The ADF-NALU's.

${ }^{132}$ International Crisis Group (ICG), Eastern Congo: The ADF-NALU's; Titeca and Vlassenroot, "Rebels without borders."

${ }^{133}$ Scorgie, "Peripheral Pariah;" Scorgie-Porter, "Economic Survival."

134 Titeca and Vlassenroot, "Rebels without borders."

${ }^{135}$ Scorgie, "The Allied Democratic Forces"

${ }^{136}$ Ibid.

${ }^{137}$ Scorgie, "Peripheral Pariah."

${ }^{138}$ Scorgie, "Peripheral Pariah;" Titeca and Vlassenroot, "Rebels without borders."

${ }^{139}$ Scorgie-Porter, "Economic Survival," 203.

${ }^{140}$ Ibid.

${ }^{141}$ Human Rights Watch, DR Congo: War Crimes by M23, Congolese Army, February 5,2013, https://www.hrw.org/news/2013/02/05/dr-congo-war-crimes-m23-congolese-army

${ }^{142}$ International Crisis Group (ICG), Eastern Congo: The ADF-NALU's.

${ }^{143}$ Alusala, et al., Final Report; Scorgie-Porter, "Economic Survival."

${ }^{144}$ Claude Muhindo Sengenya, " A counterinsurgency failure in eastern Congo," September 11, 2015, http://www.irinnews.org/report/101983/a-counterinsurgency-failure-in-eastern-congo

${ }^{145}$ International Crisis Group (ICG), Eastern Congo: The ADF-NALU's.

146 Titeca and Vlassenroot, "Rebels without borders."

${ }^{147}$ Scorgie, "Peripheral Pariah;" International Crisis Group (ICG), Eastern Congo: The ADFNALU's.

${ }^{148}$ Jonathan Fisher, "International Perceptions and African Agency: Uganda and its Donors 1986-2010” (DPhil thesis, St Antony's College, University of Oxford, 2011). 
${ }^{149}$ Fawzia Sheikh, "New Danger from Ugandan Rebel Group?" Institute of War and Peace Reporting, Africa Reports 36 (6 June 2005).

${ }^{150}$ Titeca and Vlassenroot, "Rebels without borders."

151 "Uganda's Rising Threat."

${ }^{152}$ Ibid. 